\title{
Altered placental DNA methylation patterns associated with maternal smoking: current perspectives
}

This article was published in the following Dove Press journal:

Advances in Genomics and Genetics

7 May 2015

Number of times this article has been viewed

\author{
Jennifer ZJ Maccani \\ Matthew A Maccani \\ Penn State Tobacco Center of \\ Regulatory Science, College of \\ Medicine, Department of Public \\ Health Sciences, Hershey, PA, USA
}

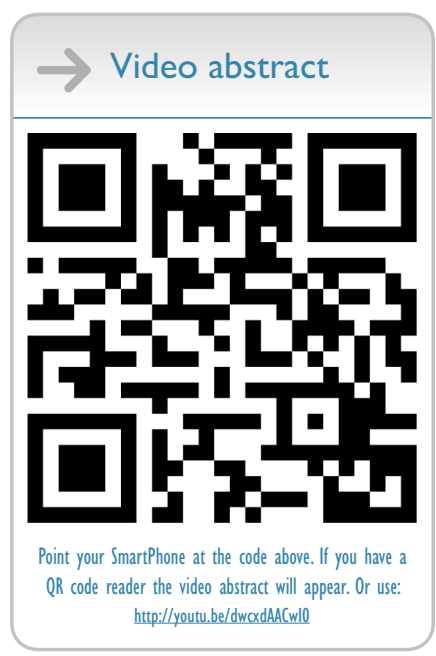

Correspondence: Jennifer ZJ Maccani Tobacco Center of Regulatory Science, Public Health Sciences Department, Suite PSHCl T3425, 500 University Drive, PO Box 850, Hershey, PA 17033-0850, USA

Tel + I 71753 I 0003 ext 289575

Fax + I 717 53I 0480

Email jmaccani@phs.psu.edu
Abstract: The developmental origins of health and disease hypothesis states that adverse early life exposures can have lasting, detrimental effects on lifelong health. Exposure to maternal cigarette smoking during pregnancy is associated with morbidity and mortality in offspring, including increased risks for miscarriage, stillbirth, low birth weight, preterm birth, asthma, obesity, altered neurobehavior, and other conditions. Maternal cigarette smoking during pregnancy interferes with placental growth and functioning, and it has been proposed that this may occur through the disruption of normal and necessary placental epigenetic patterns. Epigenome-wide association studies have identified a number of differentially methylated placental genes that are associated with maternal smoking during pregnancy, including RUNX3, PURA, GTF2H2, GCA, GPR135, and HKR1. The placental methylation status of RUNX3 and NR3C1 has also been linked to adverse infant outcomes, including preterm birth and low birth weight, respectively. Candidate gene analyses have also found maternal smoking-associated placental methylation differences in the NR3C1, CYP1A1, HTR2A, and HSD11B2 genes, as well as in the repetitive elements LINE-1 and AluYb8. The differential methylation patterns of several genes have been confirmed to also exhibit altered gene expression patterns, including CYP1A1, CYP19A1, $N R 3 C 1$, and HTR2A. Placental methylation patterns associated with maternal smoking during pregnancy may be largely gene-specific and tissue-specific and, to a lesser degree, involve global changes. It is important for future research to investigate the mechanistic roles that these differentially methylated genes may play in mediating the association between maternal smoking during pregnancy and disease in later life, as well as to elucidate the potential influence of emerging tobacco product use during pregnancy, including the use of electronic cigarettes, on placental epigenetics.

Keywords: pregnancy, epigenetics, prenatal, placenta, tobacco

\section{Introduction}

According to the developmental origins of health and disease hypothesis, in utero environmental exposures may alter fetal programming and influence the risk of disease in later life, ${ }^{1-4}$ including risk for cardiovascular disease, diabetes, asthma, cancer, and other conditions. ${ }^{5-10}$ Despite the significant offspring morbidity and mortality associated with maternal cigarette smoking during pregnancy (MCSDP), ${ }^{11-20} 10 \%-12 \%$ of US women smoke cigarettes during pregnancy. ${ }^{21,22}$ This can allow toxicants, including nicotine, to cross the placenta and disrupt placental functioning, ${ }^{23,24}$ which may result in fetal programming of later-life disease risk via alterations to normal placental epigenetic mechanisms, whereby changes in gene expression occur without direct changes to the DNA sequence. ${ }^{25-27}$ 
Four main modes of epigenetic regulation are known, ie, non-coding RNA-mediated regulation, histone modifications, imprinting, and DNA methylation, ${ }^{26}$ with DNA methylation being the most extensively studied. When a methyl group is added to the $5^{\prime}$ position of cytosine, DNA takes on a stable, transcriptionally less active and potentially inactive conformation that can repress or silence gene expression, particularly when methylation occurs within gene promoter regions. ${ }^{28-33}$ These methylation marks are often found in clusters of cytosine-guanine dinucleotide pairs called $\mathrm{CpG}$ islands. ${ }^{34}$ Normal methylation patterns are critical to many cellular functions, particularly in the placenta where correct cellular functioning is crucial to fetal development. ${ }^{35}$

It has been theorized that the placenta may act as a functional record of in utero environmental quality. ${ }^{35}$ Nicotine, for example, crosses the placenta, ${ }^{11}$ and some MCSDP-associated perturbations to normal placental epigenetic patterns are also associated with adverse infant health outcomes, ${ }^{36-42}$ including preterm birth, ${ }^{42}$ birth weight, ${ }^{43}$ and neurobehavioral outcomes. ${ }^{44}$ MCSDP-associated methylation patterns have also been found in tissues other than the placenta. ${ }^{36}$

This review summarizes what is known about the influence of MCSDP on placental methylation patterns, which may be associated with fetal programming of disease risk in later life.

\section{Cigarette smoking in pregnancy: known risks to fetal health and development}

Cigarette smoking is detrimental to health and linked to adverse health outcomes, including lung and other cancers, ${ }^{45-47}$ asthma, ${ }^{48}$ chronic obstructive pulmonary disease, ${ }^{48}$ autoimmune diseases, ${ }^{49}$ and adverse fertility outcomes in women ${ }^{50}$ and men, ${ }^{51}$ both in smokers themselves and those exposed to secondhand smoke. Cigarette smoking is associated with deleterious effects on ovarian steroidogenesis and gametogenesis, oocyte maturity, ovulation, fertilization, and implantation. ${ }^{52}$ Animal models of nicotine exposure have revealed associated oocyte apoptosis ${ }^{53}$ and reduced sperm quality. ${ }^{54}$ MCSDP has also been linked to increased risk of stillbirth ${ }^{55}$ and miscarriage. ${ }^{56}$ These associations may be biologically explained by the ability of cigarette smoke components to interfere with placental development.

MCSDP negatively affects the processes of trophoblast migration and invasion, which are primarily accomplished by extravillous trophoblast cells ${ }^{57}$ and allow the placenta to anchor in the uterine wall. ${ }^{58}$ By negatively impacting the function of these placental cell types, MCSDP can increase the risk of placenta previa, placental abruption, ${ }^{59}$ and other reproductive problems. MCSDP is associated with detriments to infant neurobehavior ${ }^{15,16,60-64}$ and the development of autoimmune diseases. ${ }^{65-67}$ Both active ${ }^{68-73}$ and passive ${ }^{71,73-75}$ MCSDP are linked to small-for-gestationalage infants.

These disruptions to normal placental growth and development can be devastating to fetal growth. The placenta plays a crucial role in providing the fetus with oxygen and nutrients, allowing gas and waste exchange, and producing important hormones and other compounds necessary for fetal development. ${ }^{35,76-79}$ The metabolic activity of the placenta also protects the fetus from many potentially harmful environmental toxicants, ${ }^{76-79}$ but certain heavy metals, ${ }^{80,81}$ cocaine, ${ }^{82}$ and nicotine ${ }^{11}$ cross this selectively permeable membrane. Changes that affect placental gene expression, such as epigenetic alterations, may have harmful downstream effects not only on placental functioning, but on the health of the developing infant. ${ }^{35}$

\section{Overview of altered DNA methylation patterns associated with MCSDP}

DNA methylation patterns are established de novo early in pregnancy following a post-fertilization wave of demethylation in the early embryo. ${ }^{28,83}$ DNA methylation involves the addition of a methyl group via a covalent bond to the $5^{\prime}$ position of cytosine, which occurs almost exclusively in the context of $\mathrm{CpG}$ dinucleotides ${ }^{35}$ Methylated $\mathrm{CpGs}$, which mostly occur in clusters known as $\mathrm{CpG}$ islands, cannot be effectively bound by transcription factors, leading to reduction or silencing of gene expression. ${ }^{84}$ This process often occurs in gene promoter regions, where precise control of gene expression is necessary for cellular growth, differentiation, and functioning. ${ }^{39}$ Thus, pregnancy and, in particular, the first trimester, is a critical window during which environmental toxicant exposures may elicit detrimental effects on normal DNA methylation and gene expression patterns in multiple tissues. These exposures can have consequences for the developing fetus, which may continue throughout the life course.

Due to the stability of the covalent bond linking methyl groups to cytosine residues, aberrant DNA methylation patterns established early in life may persist into postnatal and adult life. Contrastingly, these aberrant DNA methylation patterns may also comprise an array of biomarkers for adverse early life exposures and serve to identify at-risk infants exposed to MCSDP. ${ }^{42}$

Placental DNA methylation patterns may serve as mechanistic links between in utero exposures and adverse infant 
health outcomes. ${ }^{8,37,42,84-87}$ Epigenome-wide association studies (EWAS) have observed associations between MCSDP and placental methylation patterns in multiple genomic regions, ${ }^{37,41,42}$ although one study found associations between MCSDP and methylation in cord blood only ${ }^{88}$ EWAS studies have also observed loci associated with both MCSDP and known smoking-associated adverse infant health outcomes, including birth weight ${ }^{37,41}$ and pre-term birth. ${ }^{42}$ These studies may provide mechanistic insight into the links between MCSDP and pre-term birth or low birth weight. ${ }^{12,14}$

\section{Genetic pathways associated with MCSDP}

Table 1 describes placental methylation patterns associated with exposure to nicotine or MCSDP.

EWAS findings have elucidated potentially relevant genes and pathways that may mediate prenatal exposure to MCSDP and disease risk in later life. Many studies have employed the Illumina Infinium HumanMethylation27 BeadArray, ${ }^{89}$ which assesses the methylation status of $>27,000 \mathrm{CpG}$ loci following DNA bisulfite modification. This method allows for detection of methylated cytosine residues by treating DNA with bisulfite, which converts unmethylated cytosines to uracil; methylation is protective against conversion to uracil. Once converted, DNA samples are hybridized to array probes, and percent methylation at $>27,000$ loci is measured in beta values ranging from 0 (absence of methylation) to 1 (complete methylation). The advent of the more comprehensive Infinium HumanMethylation450 BeadArray, which interrogates $>450,000 \mathrm{CpG}$ loci, ${ }^{90}$ has allowed more extensive epigenome-wide coverage. One such study ${ }^{91}$ found placental methylation patterns associated with nicotine exposure during pregnancy in the GTF2H2C and GTF $2 \mathrm{H} 2 \mathrm{D}$ genes (see Table 1).

MCSDP-associated genes discovered via the Illumina HumanMethylation 27 and 450 BeadArrays include $R U N X 3,{ }^{42}$ PURA,${ }^{41}$ GTF 2H2, ${ }^{41,91}$ GCA, GPR135, and HKR1 ${ }^{41}$ (Table 1). Although the placental function of $R U N X 3$ has not been elucidated, $R U N X 3$ is important for cellular differentiation and development in neuronal cells, T-cells, macrophages, and dendritic cells. ${ }^{92-99}$ As a tumor suppressor gene, RUNX3 interacts with $\beta$-catenin and increases $p 27, R b$, and TIMP-1 expression when upregulated. ${ }^{100-102} R U N X 3$ is associated with numerous cancers, ${ }^{98,101,103-108}$ including bladder cancer in smokers. ${ }^{109}$ A potential role also exists for $R U N X 3$ to mediate the relationship between MCSDP and asthma and airway hyperresponsiveness, ${ }^{42,110-116}$ as has been observed in murine models. ${ }^{117,118}$

Suter et $\mathrm{al}^{41}$ found MCSDP-associated methylation alterations in a number of genes regulating DNA replication, excision repair, cellular membrane fusion, G-protein coupled receptor activity, and transcriptional regulation,

Table I Studies observing differential placental methylation patterns associated with in utero exposure to nicotine or to maternal cigarette smoking during pregnancy

\begin{tabular}{|c|c|c|c|c|c|}
\hline Reference & $\mathbf{n}$ & $\begin{array}{l}\text { Methodology used to determine } \\
\text { placental methylation status }\end{array}$ & Genes or elements identified & $P$-values & $\begin{array}{l}\text { Associated health } \\
\text { outcomes }\end{array}$ \\
\hline Appleton et al ${ }^{121}$ & 444 & Bisulfite pyrosequencing & $H S D / I B 2$ & $<0.05,<0.10$ & NA \\
\hline Chhabra et al91 & 80 & $\begin{array}{l}\text { Illumina HumanMethylation } 450 \\
\text { BeadChip array }\end{array}$ & GTF2H2C, GTF2H2D & $\begin{array}{l}2.87 \times 10^{-06} \\
3.48 \times 10^{-05}\end{array}$ & NA \\
\hline Maccani et al ${ }^{42}$ & 206 & $\begin{array}{l}\text { Illumina HumanMethylation } 27 \\
\text { BeadChip array; bisulfite } \\
\text { Pyrosequencing }\end{array}$ & RUNX3 & 0.04 & Preterm birth \\
\hline Paquette et al ${ }^{120}$ & 444 & Bisulfite pyrosequencing & $H T R 2 A$ & $0.0008-0.02$ & $\begin{array}{l}\text { Infant neurobehavior } \\
\text { (NICU Network } \\
\text { Neurobehavioral Scales } \\
\text { [NNNS]) }\end{array}$ \\
\hline Suter et $\mathrm{al}^{40}$ & 34 & Bisulfite sequencing & CYPIAI & 0.027 & NA \\
\hline Suter et $\mathrm{al}^{41}$ & 36 & $\begin{array}{l}\text { Illumina HumanMethylation } 27 \\
\text { BeadChip array; bisulfite sequencing }\end{array}$ & $\begin{array}{l}\text { STX5, FUTII, TUSC3, FANI, } \\
\text { and ZNF67I associated with both } \\
\text { smoking and birth weight; PURA, } \\
\text { GTF2H2, GCA, GPRI35, and } \\
\text { HKRI associated with smoking }\end{array}$ & $\begin{array}{l}7.66 \times 10^{-10} \\
1.48 \times 10^{-06}\end{array}$ & Birth weight reduction \\
\hline Stroud et al $\left.\right|^{119}$ & 45 & Bisulfite pyrosequencing & $\mathrm{NR3CI}$ & 0.024 & $\begin{array}{l}\text { Infant basal and reactive } \\
\text { cortisol over the first } \\
\text { postnatal month }\end{array}$ \\
\hline $\begin{array}{l}\text { Wilhelm-Benartzi } \\
\text { et } \mathrm{al}^{37}\end{array}$ & 380 & $\begin{array}{l}\text { Bisulfite pyrosequencing; Illumina } \\
\text { HumanMethylation } 27 \text { BeadChip array }\end{array}$ & LINE-I; AluYb8 & $0.01,<0.0001$ & Birth weight percentile \\
\hline
\end{tabular}

Abbreviations: NA, not applicable; NICU, Neonatal Intensive Care Unit; n, sample size. 
potentially highlighting the placental genomic damage incurred by exposure to MCSDP. The array-based findings in both studies were validated by gold-standard bisulfite pyrosequencing. ${ }^{41,42}$

The findings of differential GTF2H2 methylation by Suter et al were confirmed in 2014 by Chhabra et a ${ }^{91}$ (see Table 1 ), who observed differential GTF2H2C and GTF2H2D methylation associated with in utero nicotine exposure. ${ }^{91}$

Candidate gene studies have also elucidated links between MCSDP and altered placental methylation patterns. Most studies have utilized bisulfite pyrosequencing to interrogate the methylation status of candidate gene regions of interest. Candidate genes of potential interest that have been associated with MCSDP include NR3Cl, ${ }^{119} \mathrm{CYP} 1 \mathrm{Al},{ }^{40} \mathrm{HTR} 2 \mathrm{~A},{ }^{120}$ and $H S D 11 B .{ }^{121} N R 3 C 1$, better known as the glucocorticoid receptor gene, and $H S D 11 B 2$, the $11 \beta$-hydroxysteroid dehydrogenase type 2 (11- $\beta$-HSD2) gene, play important roles in stress response. ${ }^{122}$ Placental methylation status of $\mathrm{NR} 3 \mathrm{Cl}$ has been previously associated with infant birth weight ${ }^{43}$ and neurobehavior, ${ }^{123,124}$ and placental methylation status of $11-\beta-H S D$ has been associated with infant growth ${ }^{125}$ and neurobehavior. ${ }^{124,125}$ The 11- $\beta$-HSD2 enzyme catalyzes the conversion of active cortisol into inactive cortisone, thus regulating the availability of glucocorticoids to the glucocorticoid receptor. ${ }^{122}$ Placental cortisol is also associated with postnatal weight gain, ${ }^{126}$ underscoring the potential for this pathway as a marker of infant health outcomes. The relationship between placental NR3C1 methylation, MCSDP, and birth weight ${ }^{41,43,127}$ is likely a complex one and birth weight may be a proxy measure for multiple interplaying in utero factors that can influence fetal growth and development.

CYP1A1 is a xenobiotic-processing enzyme known to be involved in the phase I metabolism of potentially carcinogenic compounds found in cigarette smoke, including polycyclic aromatic hydrocarbons. ${ }^{40}$ Suter et $\mathrm{al}^{40}$ found that CYP1A1 expression is upregulated by MCSDP via a mechanism of placental CYP1A1 promoter hypomethylation, suggesting important roles for placental methylation alterations in the physiological response to this exposure.

HTR $2 A$, or the serotonin receptor gene, is expressed in placental tissue and is regulated by DNA methylation. ${ }^{120,128}$ Although its functional role in placental tissue has yet to be fully elucidated, Paquette et al ${ }^{120}$ recently observed MCSDP-associated placental HTR2A methylation, adding to a growing literature linking placental $H T R 2 A$ to placental implantation $^{129}$ and neurodevelopment. ${ }^{130,131}$

In addition to these candidate gene studies, WilhelmBenartzi et $\mathrm{al}^{37}$ observed associations between MCSDP and methylation of the repetitive elements LINE-1 and AluYb8 (see Table 1). This partly confirmed findings by Moore et al, ${ }^{132}$ who showed that cytosine methylation levels differ according to smoking status. The methylation levels of these repetitive elements were, in turn, associated with epigenomewide placental methylation patterns as measured by the $27 \mathrm{~K}$ array platform. ${ }^{37}$ Methylation of repetitive elements, which comprise roughly $50 \%$ of the human genome, is important for the maintenance of genomic stability. ${ }^{133,134}$ These findings suggest that placental methylation may be an indicator of underlying functional alterations to normal placental development that can be perturbed by environmental toxicant exposures, such as exposure to MCSDP.

\section{Functional consequences: changes in gene expression and implications for future disease risk}

Several studies ${ }^{40,43,120,123,135}$ have found MCSDP-associated placental gene expression patterns, and these findings are supported by studies of placental methylation changes occurring concomitantly with changes in expression of relevant genes. In particular, one study found 241 genes to be differentially expressed in the placentas of infants born to smoking mothers, many of which were related to xenobiotic metabolism, collagen, coagulation and thrombosis. ${ }^{135}$ Another genomewide study found 174 genes to be differentially expressed in the placenta, including CYP1A1 and CYP19A1, perhaps indicating a response to the oxidative stress induced by MCSDP. ${ }^{136}$ A third study ${ }^{137}$ found 329 genes to be differentially expressed in the placentas of infants exposed to MCSDP, including the additional cytochrome P450 family gene CYP1B1. These findings are consistent not only with other studies linking active and passive MCSDP with oxidative stress ${ }^{138-141}$ and the induction of the hypoxia-sensitive protein HIF $1 \alpha,{ }^{142}$ but also with the findings of Suter et al, ${ }^{40,41}$ who noted that placental methylation and expression changes occurred within gene regions related to xenobiotic processing, oxidative stress response, and hypoxia.

Other groups have also demonstrated MCSDP-related changes in gene expression associated with alterations in placental methylation. One study ${ }^{120}$ observed both placental methylation and expression alterations in the HTR $2 A$ gene, while Stroud et $\mathrm{al}^{119}$ found NR3C1 placental methylation alterations associated with MCSDP and altered cortisol levels. Additional work has suggested that $\mathrm{NR} 3 \mathrm{Cl}$ methylation status is correlated with glucocorticoid receptor expression. ${ }^{43,123}$ Taken together, these studies suggest that methylation alterations in these genes within placental tissue 
may have functional consequences for important placental pathways.

MCSDP is associated with a host of diseases and disorders in infancy, childhood, and later life..$^{11-19,22}$ These include pre-term birth, ${ }^{11,12}$ fetal growth retardation and intrauterine growth restriction, ${ }^{13,14}$ adverse neurobehavioral outcomes, ${ }^{15,16}$ obesity, ${ }^{17-19}$ and asthma. ${ }^{10,84,110-116}$ In fact, even grand-maternal smoke exposure has been associated with an increased risk of asthma in grandchildren, ${ }^{10}$ although a recent study of children from the Avon Longitudinal Study of Parents and Children did not reveal such an association. ${ }^{143}$ Nonetheless, epigenetic mechanisms have been implicated in the relationship between grand-maternal and maternal smoking during pregnancy and risk of asthma and airway hyper-responsiveness in offspring. ${ }^{84,144}$ EWAS have borne out this finding, showing that alterations in placental methylation associated with both MCSDP and adverse infant health outcomes, such as pre-term birth, occur in genes associated with asthma and airway hyper-responsiveness (such as $R U N X 3$ ). ${ }^{42}$ These findings suggest that epigenetic mechanisms may underlie MCSDP-associated adverse health outcomes.

\section{Conclusion and future directions}

Although a growing body of literature exists on MCSDPassociated alterations in placental methylation, there is much work yet to be done to elucidate the specific signaling pathways and mechanisms involved in mediating the relationship between MCSDP and disease risk in later life. Ongoing cohort studies may help to further discern the risks posed by MCSDP to infant and child health outcomes, including risks for respiratory disorders, ${ }^{110,111,113,114,116}$ adverse neurodevelopmental outcomes, ${ }^{15,16,60,61,64,85,145}$ and obesity, ${ }^{17-19}$ all of which have been linked to MCSDP.

One such cohort study is the Rhode Island Child Health Study (RICHS), a population-based birth cohort enrolling mother-infant pairs at the Women and Infants' Hospital in Providence, RI, USA. ${ }^{146}$ RICHS recruits newborn infants and their mothers following delivery and seeks to examine how the prenatal environment may influence postnatal health and neurobehavioral outcomes. Several important findings describing epigenetic links between the prenatal environment and postnatal outcomes have already been published from this cohort ${ }^{44,146-150}$ and work is ongoing to examine additional mechanistic links between prenatal exposures and a variety of postnatal outcomes.

The Norwegian Mother and Child Cohort Study has also published several key studies on MCSDP and DNA methylation patterns in cord blood, ${ }^{151,152}$ fetal loss, ${ }^{153}$ plasma lipid levels in adult offspring, ${ }^{154}$ and infant behavioral outcomes. ${ }^{155}$ This cohort will likely continue to produce important data on MCSDP-associated disease risk in later life in the coming years.

Both epigenome-wide and candidate-based studies of placental methylation patterns have yielded intriguing results for genes of potential biological interest that should be further investigated in future studies, including $R U N X 3,{ }^{42} C Y P 1 A 1,{ }^{40}$ NR3C1, ${ }^{119}$ HTR 2A, ${ }^{120}$ HSD1 1B2, ${ }^{121}$ PURA,${ }^{41}$ GTF2H2, ${ }^{41,91}$ GCA, GPR135, and HKR1. ${ }^{41}$ The methylation status of genomic repetitive elements, such as LINE-1 and AluYb8, has also shown promise as a potential biomarker of MCSDP. ${ }^{37}$ It is important to note that an additional gene, the aryl hydrocarbon receptor repressor $(A H R R)$, has also been recently investigated with respect to exposure to MCSDP, but while an association was found within this gene in cord blood mononuclear cells, a similar association was not found in placental tissue. ${ }^{156}$

Cumulatively, these results suggest that MCSDPassociated placental methylation is gene-specific, and perhaps, to a lesser degree, can also occur epigenome-wide, a conclusion previously drawn by Suter and Aagaard. ${ }^{133}$ These patterns also appear to be tissue-specific, as studies investigating MCSDP-associated methylation patterns have observed alterations in genes with only partial overlap in various tissues of interest. These genes include FRMD4A, ${ }^{157,158}$ C11orf52, ${ }^{157}$ AHRR, ${ }^{151,152}$ CYP1A1, GFI1, ${ }^{152}$ ATP9A, GALNT2, and MEG3. ${ }^{158}$ Consideration should also be given to the role that additional in utero factors may play in placental methylation patterns. The studies described above have largely attempted to control for or match samples on potential confounders, including infant sex, ${ }^{37,40-42,120,121}$ maternal age, ${ }^{37,41,42,121}$ maternal pre-pregnancy body mass index, ${ }^{37,41,121}$ birth weight, ${ }^{42,120}$ delivery method, ${ }^{42}$ gestational age or birth weight percentile, ${ }^{41,120,121}$ maternal education, ${ }^{120}$ race/ethnicity, ${ }^{37,41,121}$ and other maternal factors, ${ }^{37,40}$ including smoking status for analyses of methylation patterns associated with infant health outcomes. ${ }^{37,119,120}$ Future studies may reveal concordance in genes identified, although to date only GTF $2 H 2^{41,91}$ has been differentially methylated in association with MCSDP or nicotine exposure in multiple studies.

Concordance of methylation patterns between tissues and life stages should also be investigated. For example, two studies $^{159,160}$ observed smoking status-associated peripheral blood methylation patterns in adults, but these findings have yet to be confirmed in the placenta. Investigation of these findings, as well as epigenome-wide analyses of placental methylation patterns differing between infants exposed to MCSDP throughout pregnancy versus mothers who quit, would help to 
elucidate whether placental methylation patterns are reversible with smoking cessation. As methylation is known to exhibit a degree of plasticity with respect to environmental and stochastic factors, ${ }^{87}$ demonstration of reversible methylation with smoking cessation would have implications for variations in MCSDP-associated health risks.

It will be important for future studies to focus on the use of emerging tobacco products as unique prenatal exposures that may be associated with unique gene-specific and tissue-specific methylation patterns. Such emerging tobacco products include electronic (e-)cigarettes, electronic nicotine delivery devices which, as of February 2015, are under consideration for regulation at the federal level by the US Food and Drug Administration. ${ }^{161}$ Some types of e-cigarettes are capable of producing nicotine yields at levels comparable with those in traditional cigarettes, ${ }^{162}$ but e-cigarette liquids and vapors contain different compounds, such as propylene glycol and specific flavors, not found in traditional cigarettes. ${ }^{163-165}$ E-cigarette flavors may also be formulated with other compounds that are not found in traditional cigarettes. The influence of prenatal exposure to e-cigarettes on the placenta and developing fetus remains unknown, and it is important to investigate such exposures during pregnancy or in in vitro models. It will also be important to investigate placental methylation alterations associated with prenatal e-cigarette exposure and, if they exist, to compare these e-cigarette exposure-associated placental methylation profiles with the placental methylation profiles previously associated with MCSDP.

In conclusion, while a growing literature exists on MCSDP-associated placental methylation, work remains to be done to fully investigate the gene-specific and tissue-specific mechanisms that underlie the relationship between MCSDP and disease in later life. This knowledge will help identify at-risk infants exposed to MCSDP and hopefully help to formulate effective interventions to improve infant health. Future studies should examine placental methylation alterations associated with prenatal exposure to emerging tobacco products as well, so that information on potential health effects can be disseminated to women who are pregnant or of child-bearing age. Collectively, such efforts will help to further understand links between prenatal tobacco exposure and infant and child health outcomes, with the goal of better elucidating the greater developmental origins of health and disease.

\section{Acknowledgments}

This review was written while JZJM and MAM were postdoctoral fellows at Brown University and was supported by grants from the National Heart, Lung, and Blood Institute (grant T32HL076134-04 to JZJM) and the National Institute of Mental Health (grant 5T32MH019927-20 to MAM). This review was revised while JZJM and MAM were at the Tobacco Center of Regulatory Science at Penn State College of Medicine, where JZJM and MAM are both currently postdoctoral scholars and are supported by grant P50-DA-036107 from the National Institutes of Health. Therefore this work was supported in part by the National Institute on Drug Abuse of the National Institutes of Health and the Center for Tobacco Products of the U.S. Food and Drug Administration (under Award Number P50-DA-036107). The content is solely the responsibility of the authors and does not necessarily represent the official views of the National Institutes of Health or the Food and Drug Administration.

\section{Disclosure}

The authors have no conflicts of interest to disclose.

\section{References}

1. Barker DJ. Maternal nutrition, fetal nutrition, and disease in later life. Nutrition. 1997;13(9):807-813.

2. Barker DJ. In utero programming of chronic disease. Clin Sci (Lond). 1998;95(2):115-128.

3. Silveira PP, Portella AK, Goldani MZ, Barbieri MA. Developmental origins of health and disease (DOHaD). J Pediatr (Rio J). 2007;83(6): 494-504.

4. Hales CN, Barker DJ. Type 2 (non-insulin-dependent) diabetes mellitus: the thrifty phenotype hypothesis. Diabetologia. 1992;35(7): 595-601.

5. Kulis M, Esteller M. DNA methylation and cancer. Adv Genet. 2010;70: $27-56$.

6. Burdge GC, Lillycrop KA. Nutrition, epigenetics, and developmental plasticity: implications for understanding human disease. Annu Rev Nutr. 2010;30:315-339.

7. Herz U, Joachim R, Ahrens B, Scheffold A, Radbruch A, Renz H. Prenatal sensitization in a mouse model. Am J Respir Crit Care Med. 2000;162(3 Pt 2):S62-S65.

8. Prescott SL, Clifton V. Asthma and pregnancy: emerging evidence of epigenetic interactions in utero. Curr Opin Allergy Clin Immunol. 2009;9(5):417-426.

9. Hollingsworth JW, Maruoka S, Boon K, et al. In utero supplementation with methyl donors enhances allergic airway disease in mice. J Clin Invest. 2008;118(10):3462-3469.

10. Li YF, Langholz B, Salam MT, Gilliland FD. Maternal and grandmaternal smoking patterns are associated with early childhood asthma. Chest. 2005;127(4):1232-1241.

11. Simpson WJ. A preliminary report on cigarette smoking and the incidence of prematurity. Am J Obstet Gynecol. 1957;73(4):807-815.

12. Shiono PH, Klebanoff MA, Rhoads GG. Smoking and drinking during pregnancy. Their effects on preterm birth. JAMA. 1986;255(1): 82-84.

13. Olsen J. Cigarette smoking in pregnancy and fetal growth. Does the type of tobacco play a role? Int J Epidemiol. 1992;21(2):279-284.

14. Miller HC, Hassanein K, Hensleigh PA. Fetal growth retardation in relation to maternal smoking and weight gain in pregnancy. Am J Obstet Gynecol. 1976;125(1):55-60.

15. Stroud LR, Paster RL, Goodwin MS, et al. Maternal smoking during pregnancy and neonatal behavior: a large-scale community study. Pediatrics. 2009;123(5):e842-e848. 
16. Stroud LR, Paster RL, Papandonatos GD, et al. Maternal smoking during pregnancy and newborn neurobehavior: effects at 10 to 27 days. J Pediatr. 2009;154(1):10-16.

17. Toschke AM, Montgomery SM, Pfeiffer U, von Kries R. Early intrauterine exposure to tobacco-inhaled products and obesity. Am J Epidemiol. 2003;158(11):1068-1074.

18. von Kries R, Bolte G, Baghi L, Toschke AM. Parental smoking and childhood obesity - is maternal smoking in pregnancy the critical exposure? Int J Epidemiol. 2008;37(1):210-216.

19. Oken E, Levitan EB, Gillman MW. Maternal smoking during pregnancy and child overweight: systematic review and meta-analysis. Int J Obes (Lond). 2008;32(2):201-210.

20. Tong VT, Jones JR, Dietz PM, D’Angelo D, Bombard JM. Trends in smoking before, during, and after pregnancy - Pregnancy Risk Assessment Monitoring System (PRAMS), United States, 31 sites, 2000-2005. MMWR Surveill Summ. 2009;58(4):1-29.

21. Goodwin RD, Keyes K, Simuro N. Mental disorders and nicotine dependence among pregnant women in the United States. Obstet Gynecol. 2007;109(4):875-883.

22. Tong VT, Dietz PM, Morrow B, et al. Trends in smoking before, during, and after pregnancy - Pregnancy Risk Assessment Monitoring System, United States, 40 sites, 2000-2010. MMWR Surveill Summ. 2013;62(6):1-19.

23. Burris HH, Rifas-Shiman SL, Baccarelli A, et al. Associations of LINE-1 DNA methylation with preterm birth in a prospective cohort study. J Dev Orig Health Dis. 2012;3(3):173-181.

24. Koren G, Klein J, Forman R, Graham K, Phan MK. Biological markers of intrauterine exposure to cocaine and cigarette smoking. Dev Pharmacol Ther. 1992;18(3-4):228-236.

25. Rakyan VK, Down TA, Balding DJ, Beck S. Epigenome-wide association studies for common human diseases. Nat Rev Genet. 2011;12(8): 529-541.

26. Bird A. Perceptions of epigenetics. Nature. 2007;447(7143): 396-398.

27. Prescott S, Saffery R. The role of epigenetic dysregulation in the epidemic of allergic disease. Clin Epigenetics. 2011;2(2): 223-232.

28. Ameri A, Alidoosti A, Hosseini SY, et al. [Prognostic value of promoter hypermethylation of retinoic acid receptor beta (RARB) and CDKN2 (p16/MTS1) in prostate cancer]. Chung-Kuo Yen Cheng Yen Chiu. 2011;23(4):306-311. Chinese.

29. Zilberman D, Gehring M, Tran RK, Ballinger T, Henikoff S. Genomewide analysis of Arabidopsis thaliana DNA methylation uncovers an interdependence between methylation and transcription. Nat Genet. 2007;39(1):61-69.

30. Zhang X, Yazaki J, Sundaresan A, et al. Genome-wide high-resolution mapping and functional analysis of DNA methylation in arabidopsis. Cell. 2006;126(6):1189-1201.

31. Ball MP, Li JB, Gao Y, et al. Targeted and genome-scale strategies reveal gene-body methylation signatures in human cells. Nat Biotechnol. 2009;27(4):361-368.

32. Hellman A, Chess A. Gene body-specific methylation on the active X chromosome. Science. 2007;315(5815):1141-1143.

33. Rauch TA, Wu X, Zhong X, Riggs AD, Pfeifer GP. A human B cell methylome at 100-base pair resolution. Proc Natl Acad Sci USA. 2009; 106(3):671-678

34. Bird AP. Use of restriction enzymes to study eukaryotic DNA methylation: II. The symmetry of methylated sites supports semi-conservative copying of the methylation pattern. J Mol Biol. 1978; 118(1):49-60.

35. Maccani MA, Marsit CJ. Epigenetics in the placenta. Am J Reprod Immunol. 2009;62(2):78-89.

36. Nielsen CH, Larsen A, Nielsen AL. DNA methylation alterations in response to prenatal exposure of maternal cigarette smoking: a persistent epigenetic impact on health from maternal lifestyle? Arch Toxicol. December 6, 2014. [Epub ahead of print.]

37. Wilhelm-Benartzi CS, Houseman EA, Maccani MA, et al. In utero exposures, infant growth, and DNA methylation of repetitive elements and developmentally related genes in human placenta. Environ Health Perspect. 2012;120(2):296-302.
38. Maccani MA, Avissar-Whiting M, Banister CE, McGonnigal B, Padbury JF, Marsit CJ. Maternal cigarette smoking during pregnancy is associated with downregulation of miR-16, miR-21, and miR-146a in the placenta. Epigenetics. 2010;5(7):583-589.

39. Nelissen EC, van Montfoort AP, Dumoulin JC, Evers JL. Epigenetics and the placenta. Hum Reprod Update. 2011;17(3):397-417.

40. Suter M, Abramovici A, Showalter L, et al. In utero tobacco exposure epigenetically modifies placental CYP1A1 expression. Metabolism. 2010;59(10):1481-1490.

41. Suter M, Ma J, Harris A, et al. Maternal tobacco use modestly alters correlated epigenome-wide placental DNA methylation and gene expression. Epigenetics. 2011;6(11):1284-1294.

42. Maccani JZ, Koestler DC, Houseman EA, Marsit CJ, Kelsey KT. Placental DNA methylation alterations associated with maternal tobacco smoking at the RUNX3 gene are also associated with gestational age. Epigenomics. 2013;5(6):619-630.

43. Filiberto AC, Maccani MA, Koestler D, et al. Birthweight is associated with DNA promoter methylation of the glucocorticoid receptor in human placenta. Epigenetics. 2011;6(5):566-572.

44. Marsit CJ, Lambertini L, Maccani MA, et al. Placenta-imprinted gene expression association of infant neurobehavior. $J$ Pediatr. 2012;160(5):854-860. e852.

45. Wynder EL, Graham EA. Tobacco smoking as a possible etiologic factor in bronchiogenic carcinoma; a study of 684 proved cases. JAMA. 1950;143(4):329-336.

46. Mueller F. [Tobacco consumption and lung carcinoma]. Z Krebsforsch. 1939;49:57-85. German.

47. Morabia A. Quality, originality, and significance of the 1939 "Tobacco consumption and lung carcinoma" article by Mueller, including translation of a section of the paper. Prev Med. 2012;55(3): $171-177$.

48. Gratziou C, Florou A, Ischaki E, et al. Smoking cessation effectiveness in smokers with COPD and asthma under real life conditions. Respir Med. 2014;108(4):577-583.

49. Johannsen A, Susin C, Gustafsson A. Smoking and inflammation: evidence for a synergistic role in chronic disease. Periodontol 2000. 2014;64(1):111-126.

50. Merritt T, Mazela J, Merritt A. Tobacco smoking and its consequences on reproductive health: the impact of a lifestyle choices including cigarette smoke exposure on fertility and birth defects. Przegl Lek. 2013;70(10):779-783.

51. Barazani Y, Katz BF, Nagler HM, Stember DS. Lifestyle, environment, and male reproductive health. Urol Clin North Am. 2014;41(1): 55-66.

52. Cooper AR, Moley KH. Maternal tobacco use and its preimplantation effects on fertility: more reasons to stop smoking. Semin Reprod Med. 2008;26(2):204-212.

53. Asadi E, Jahanshahi M, Golalipour MJ. Effect of vitamin e on oocytes apoptosis in nicotine-treated mice. Iran J Basic Med Sci. 2012;15(3):880-884.

54. Oyeyipo IP, Raji Y, Emikpe BO, Bolarinwa AF. Effects of nicotine on sperm characteristics and fertility profile in adult male rats: a possible role of cessation. J Reprod Infertil. 2011;12(3):201-207.

55. Aliyu MH, Salihu HM, Wilson RE, Kirby RS. Prenatal smoking and risk of intrapartum stillbirth. Arch Environ Occup Health. 2007;62(2):87-92.

56. Mishra GD, Dobson AJ, Schofield MJ. Cigarette smoking, menstrual symptoms and miscarriage among young women. Aust $N \mathrm{ZJ}$ Public Health. 2000;24(4):413-420.

57. Taylor J, Pampillo M, Bhattacharya M, Babwah AV. Kisspeptin/ KISS1R signaling potentiates extravillous trophoblast adhesion to type-I collagen in a PKC- and ERK1/2-dependent manner. Mol Reprod Dev. 2014;81(1):42-54

58. Robbins JR, Skrzypczynska KM, Zeldovich VB, Kapidzic M, Bakardjiev AI. Placental syncytiotrophoblast constitutes a major barrier to vertical transmission of Listeria monocytogenes. PLoS Pathog. 2010;6(1):e1000732. 
59. Delpisheh A, Brabin L, Brabin BJ. Pregnancy, smoking and birth outcomes. Womens Health (Lond Engl). 2006;2(3):389-403.

60. Barros MC, Mitsuhiro SS, Chalem E, Laranjeira RR, Guinsburg R. Prenatal tobacco exposure is related to neurobehavioral modifications in infants of adolescent mothers. Clinics (Sao Paulo). 2011;66(9):1597-1603.

61. Hernandez-Martinez C, Arija Val V, Escribano Subias J, Canals Sans J. A longitudinal study on the effects of maternal smoking and secondhand smoke exposure during pregnancy on neonatal neurobehavior. Early Hum Dev. 2012;88(6):403-408.

62. Garcia-Algar O, Puig C, Vall O, Pacifici R, Pichini S. Effects of maternal smoking during pregnancy on newborn neurobehavior: neonatal nicotine withdrawal syndrome. Pediatrics. 2004;113(3 Pt 1):623-624.

63. Pichini S, Garcia-Algar O. In utero exposure to smoking and newborn neurobehavior: how to assess neonatal withdrawal syndrome? Ther Drug Monit. 2006;28(3):288-290.

64. Law KL, Stroud LR, LaGasse LL, Niaura R, Liu J, Lester BM. Smoking during pregnancy and newborn neurobehavior. Pediatrics. 2003; 111(6 Pt 1):1318-1323.

65. Roberts SE, Wotton CJ, Williams JG, Griffith M, Goldacre MJ. Perinatal and early life risk factors for inflammatory bowel disease. World $J$ Gastroenterol. 2011;17(6):743-749.

66. Lashner BA, Shaheen NJ, Hanauer SB, Kirschner BS. Passive smoking is associated with an increased risk of developing inflammatory bowel disease in children. Am J Gastroenterol. 1993;88(3):356-359.

67. Mahid SS, Minor KS, Stromberg AJ, Galandiuk S. Active and passive smoking in childhood is related to the development of inflammatory bowel disease. Inflamm Bowel Dis. 2007;13(4):431-438.

68. Ko TJ, Tsai LY, Chu LC, et al. Parental smoking during pregnancy and its association with low birth weight, small for gestational age, and preterm birth offspring: a birth cohort study. Pediatr Neonatol. 2014;55(1):20-27.

69. Aagaard-Tillery KM, Porter TF, Lane RH, Varner MW, Lacoursiere DY. In utero tobacco exposure is associated with modified effects of maternal factors on fetal growth. Am J Obstet Gynecol. 2008;198(1):66. e61-e66.

70. Ward C, Lewis S, Coleman T. Prevalence of maternal smoking and environmental tobacco smoke exposure during pregnancy and impact on birth weight: retrospective study using Millennium Cohort. BMC Public Health. 2007;7:81.

71. Mitchell EA, Thompson JM, Robinson E, et al. Smoking, nicotine and tar and risk of small for gestational age babies. Acta Paediatr. 2002;91(3):323-328.

72. Han JX, Gan DK, Zhai GR, Shi Y. [Case-control study on effect of passive smoking during different pregnancy term on small-for-gestationalage infants at term]. Wei Sheng Yan Jiu. 2006;35(6):788-790. Chinese.

73. Hanke W, Kalinka J, Florek E, Sobala W. Passive smoking and pregnancy outcome in central Poland. Hum Exp Toxicol. 1999;18(4):265-271.

74. Fantuzzi G, Vaccaro V, Aggazzotti G, et al. Exposure to active and passive smoking during pregnancy and severe small for gestational age at term. J Matern Fetal Neonatal Med. 2008;21(9):643-647.

75. Chen LH, Petitti DB. Case-control study of passive smoking and the risk of small-for-gestational-age at term. Am J Epidemiol. 1995;142(2): $158-165$.

76. Carney EW, Scialli AR, Watson RE, DeSesso JM. Mechanisms regulating toxicant disposition to the embryo during early pregnancy: an interspecies comparison. Birth Defects Res C Embryo Today. 2004;72(4):345-360.

77. Syme MR, Paxton JW, Keelan JA. Drug transfer and metabolism by the human placenta. Clin Pharmacokinet. 2004;43(8):487-514.

78. Sanyal MK, Li YL. Differential metabolism of benzo[alpha]pyrene in vitro by human placental tissues exposed to active maternal cigarette smoke. Birth Defects Res B Dev Reprod Toxicol. 2007;80(1): 49-56.

79. Pavek P, Smutny T. Nuclear receptors in regulation of biotransformation enzymes and drug transporters in the placental barrier. Drug Metab Rev. 2014;46(1):19-32.
80. Vahter M. Effects of arsenic on maternal and fetal health. Annu Rev Nutr. 2009;29:381-399.

81. Wier PJ, Miller RK, Maulik D, DiSant'Agnese PA. Toxicity of cadmium in the perfused human placenta. Toxicol Appl Pharmacol 1990;105(1):156-171.

82. Schenker S, Yang Y, Johnson RF, et al. The transfer of cocaine and its metabolites across the term human placenta. Clin Pharmacol Ther. 1993;53(3):329-339.

83. Cedar H, Bergman Y. Epigenetics of haematopoietic cell development. Nat Rev Immunol. 2011;11(7):478-488.

84. Rehan VK, Liu J, Naeem E, et al. Perinatal nicotine exposure induces asthma in second generation offspring. BMC Med. 2012;10:129.

85. Knopik VS, Maccani MA, Francazio S, McGeary JE. The epigenetics of maternal cigarette smoking during pregnancy and effects on child development. Dev Psychopathol. 2012;24(4):1377-1390.

86. North ML, Ellis AK. The role of epigenetics in the developmental origins of allergic disease. Ann Allergy Asthma Immunol. 2011;106(5): 355-361.

87. Novakovic B, Yuen RK, Gordon L, et al. Evidence for widespread changes in promoter methylation profile in human placenta in response to increasing gestational age and environmental/stochastic factors. BMC Genomics. 2011;12:529.

88. Michels KB, Harris HR, Barault L. Birthweight, maternal weight trajectories and global DNA methylation of LINE-1 repetitive elements. PLoS One. 2011;6(9):e25254.

89. Illumina. Infinium HumanMethylation 27 BeadChip Kits. 2011. Available from: http://support.illumina.com/array/array_kits/ infinium_humanmethylation27_beadchip_kit.ilmn. Accessed September 6, 2013.

90. Illumina. Infinium HumanMethylation450 BeadChip Kit 2014. Available from: http://www.illumina.com/products/methylation 450_beadchip_kits.ilmn. Accessed February 28, 2015.

91. Chhabra D, Sharma S, Kho AT, et al. Fetal lung and placental methylation is associated with in utero nicotine exposure. Epigenetics. 2014;9(11):1473-1484.

92. Woolf E, Brenner O, Goldenberg D, Levanon D, Groner Y. Runx3 regulates dendritic epidermal T cell development. Dev Biol. 2007;303(2):703-714

93. Zamisch M, Tian L, Grenningloh R, et al. The transcription factor Ets1 is important for CD4 repression and Runx3 up-regulation during CD8 T cell differentiation in the thymus. J Exp Med. 2009;206(12):2685-2699.

94. Tokunaga T, Hayashi A, Kadota Y, et al. Regulation of Th-POK and Runx3 in T cell development in human thymoma. Autoimmunity. 2009;42(8):653-660.

95. Klunker S, Chong MM, Mantel PY, et al. Transcription factors RUNX1 and RUNX3 in the induction and suppressive function of Foxp3+ inducible regulatory T cells. $J$ Exp Med. 2009;206(12):2701-2715.

96. Inoue K, Ozaki S, Shiga T, et al. Runx3 controls the axonal projection of proprioceptive dorsal root ganglion neurons. Nat Neurosci. 2002;5(10):946-954.

97. Sanchez-Martin L, Estecha A, Samaniego R, Sanchez-Ramon S, Vega MA, Sanchez-Mateos P. The chemokine CXCL12 regulates monocyte-macrophage differentiation and RUNX3 expression. Blood. 2011;117(1):88-97.

98. Li QL, Ito K, Sakakura C, et al. Causal relationship between the loss of RUNX3 expression and gastric cancer. Cell. 2002;109(1):113-124.

99. Puig-Kroger A, Aguilera-Montilla N, Martinez-Nunez R, et al. The novel RUNX3/p33 isoform is induced upon monocyte-derived dendritic cell maturation and downregulates IL-8 expression. Immunobiology. 2010;215(9-10):812-820.

100. Chen JS, Kuo YB, Chou YP, et al. Detection of autoantibodies against Rabphilin-3A-like protein as a potential biomarker in patient's sera of colorectal cancer. Clin Chim Acta. 2011;412(15-16):1417-1422.

101. He L, Zhao X, Wang H, et al. RUNX3 mediates suppression of tumor growth and metastasis of human CCRCC by regulating cyclin related proteins and TIMP-1. PLoS One. 2012;7(3):e32961. 
102. Ito K, Lim AC, Salto-Tellez M, et al. RUNX3 attenuates betacatenin/T cell factors in intestinal tumorigenesis. Cancer Cell. 2008;14(3):226-237.

103. Xiao WH, Liu WW. Hemizygous deletion and hypermethylation of RUNX3 gene in hepatocellular carcinoma. World J Gastroenterol. 2004;10(3):376-380.

104. Lu XX, Yu JL, Ying LS, et al. Stepwise cumulation of RUNX3 methylation mediated by Helicobacter pylori infection contributes to gastric carcinoma progression. Cancer. 2012;118(22):5507-5517.

105. Tang GH, Sun SW, He XS. [Correlation of CpG methylation status of Runx3 with pathogenesis of gastric carcinoma]. Zhonghua Bing $L i$ Xue Za Zhi. 2012;41(5):314-319. Chinese.

106. Mahapatra S, Klee EW, Young CY, et al. Global methylation profiling for risk prediction of prostate cancer. Clin Cancer Res. 2012;18(10):2882-2895.

107. Yanagawa N, Tamura G, Oizumi H, Takahashi N, Shimazaki Y, Motoyama T. Promoter hypermethylation of tumor suppressor and tumor-related genes in non-small cell lung cancers. Cancer Sci. 2003;94(7):589-592.

108. Puig-Kroger A, Corbi A. RUNX3: a new player in myeloid gene expression and immune response. J Cell Biochem. 2006;98(4):744-756.

109. Wolff EM, Liang G, Cortez CC, et al. RUNX3 methylation reveals that bladder tumors are older in patients with a history of smoking. Cancer Res. 2008;68(15):6208-6214.

110. Haberg SE, Stigum H, Nystad W, Nafstad P. Effects of pre- and postnatal exposure to parental smoking on early childhood respiratory health. Am J Epidemiol. 2007;166(6):679-686.

111. Lux AL, Henderson AJ, Pocock SJ. Wheeze associated with prenatal tobacco smoke exposure: a prospective, longitudinal study. ALSPAC Study Team. Arch Dis Child. 2000;83(4):307-312.

112. Lannero E, Wickman M, Pershagen G, Nordvall L. Maternal smoking during pregnancy increases the risk of recurrent wheezing during the first years of life (BAMSE). Respir Res. 2006;7:3.

113. Magnusson LL, Olesen AB, Wennborg H, Olsen J. Wheezing, asthma, hayfever, and atopic eczema in childhood following exposure to tobacco smoke in fetal life. Clin Exp Allergy. 2005;35(12):1550-1556.

114. Stein RT, Holberg CJ, Sherrill D, et al. Influence of parental smoking on respiratory symptoms during the first decade of life: the Tucson Children's Respiratory Study. Am J Epidemiol. 1999;149(11): 1030-1037.

115. Prabhu N, Smith N, Campbell D, et al. First trimester maternal tobacco smoking habits and fetal growth. Thorax. 2010;65(3):235-240.

116. Gilliland FD, Berhane K, Li YF, Rappaport EB, Peters JM. Effects of early onset asthma and in utero exposure to maternal smoking on childhood lung function. Am J Respir Crit Care Med. 2003;167(6):917-924.

117. Haley KJ, Lasky-Su J, Manoli SE, et al. RUNX transcription factors: association with pediatric asthma and modulated by maternal smoking. Am J Physiol Lung Cell Mol Physiol. 2011;301(5):L693-L701.

118. Fainaru O, Shseyov D, Hantisteanu S, Groner Y. Accelerated chemokine receptor 7-mediated dendritic cell migration in Runx3 knockout mice and the spontaneous development of asthma-like disease. Proc Natl Acad Sci U S A. 2005;102(30):10598-10603.

119. Stroud LR, Papandonatos GD, Rodriguez D, et al. Maternal smoking during pregnancy and infant stress response: test of a prenatal programming hypothesis. Psychoneuroendocrinology. 2014;48: 29-40.

120. Paquette AG, Lesseur C, Armstrong DA, et al. Placental HTR2A methylation is associated with infant neurobehavioral outcomes. Epigenetics. 2013;8(8):796-801.

121. Appleton AA, Armstrong DA, Lesseur C, et al. Patterning in placental 11-B hydroxysteroid dehydrogenase methylation according to prenatal socioeconomic adversity. PLoS One. 2013;8(9):e74691.

122. Stewart PM, Krozowski ZS. 11 beta-hydroxysteroid dehydrogenase. Vitam Horm. 1999;57:249-324.

123. Bromer C, Marsit CJ, Armstrong DA, Padbury JF, Lester B. Genetic and epigenetic variation of the glucocorticoid receptor (NR3C1) in placenta and infant neurobehavior. Dev Psychobiol. 2013;55(7):673-683.
124. Conradt E, Lester BM, Appleton AA, Armstrong DA, Marsit CJ. The roles of DNA methylation of NR3C1 and 11beta-HSD2 and exposure to maternal mood disorder in utero on newborn neurobehavior. Epigenetics. 2013;8(12):1321-1329.

125. Marsit CJ, Maccani MA, Padbury JF, Lester BM. Placental 11-beta hydroxysteroid dehydrogenase methylation is associated with newborn growth and a measure of neurobehavioral outcome. PLoS One. 2012;7(3):e33794.

126. Street ME, Smerieri A, Petraroli A, et al. Placental cortisol and cord serum IGFBP-2 concentrations are important determinants of postnatal weight gain. J Biol Regul Homeost Agents. 2012;26(4): 721-731.

127. Stroud LR, Papandonatos GD, Shenassa E, et al. Prenatal glucocorticoids and maternal smoking during pregnancy independently program adult nicotine dependence in daughters: a 40-year prospective study. Biol Psychiatry. 2014;75(1):47-55.

128. Sonier B, Lavigne C, Arseneault M, Ouellette R, Vaillancourt C. Expression of the 5-HT2A serotoninergic receptor in human placenta and choriocarcinoma cells: mitogenic implications of serotonin. Placenta. 2005;26(6):484-490.

129. Oufkir T, Vaillancourt C. Phosphorylation of JAK2 by serotonin 5-HT (2A) receptor activates both STAT3 and ERK1/2 pathways and increases growth of JEG-3 human placental choriocarcinoma cell. Placenta. 2011;32(12):1033-1040.

130. Sato K. Placenta-derived hypo-serotonin situations in the developing forebrain cause autism. Med Hypotheses. 2013;80(4):368-372.

131. Broekman BF, Chan YH, Goh L, et al. Influence of birth weight on internalizing traits modulated by serotonergic genes. Pediatrics. 2011;128(5):e1250-e1258.

132. Moore LE, Pfeiffer RM, Poscablo C, et al. Genomic DNA hypomethylation as a biomarker for bladder cancer susceptibility in the Spanish Bladder Cancer Study: a case-control study. The Lancet Oncol. 2008;9(4):359-366.

133. Suter MA, Aagaard K. What changes in DNA methylation take place in individuals exposed to maternal smoking in utero? Epigenomics. 2012;4(2):115-118.

134. Schulz WA, Hatina J. Epigenetics of prostate cancer: beyond DNA methylation. J Cell Mol Med. 2006;10(1):100-125.

135. Bruchova H, Vasikova A, Merkerova M, et al. Effect of maternal tobacco smoke exposure on the placental transcriptome. Placenta. 2010;31(3):186-191.

136. Huuskonen P, Storvik M, Reinisalo M, et al. Microarray analysis of the global alterations in the gene expression in the placentas from cigarette-smoking mothers. Clin Pharmacol Ther. 2008;83(4): $542-550$.

137. Votavova H, Dostalova Merkerova M, Fejglova K, et al. Transcriptome alterations in maternal and fetal cells induced by tobacco smoke. Placenta. 2011;32(10):763-770.

138. Zdravkovic T, Genbacev O, McMaster MT, Fisher SJ. The adverse effects of maternal smoking on the human placenta: a review. Placenta. 2005;26 Suppl A:S81-S86.

139. Brunnemann KD, Hoffmann D. Analytical studies on tobacco-specific N-nitrosamines in tobacco and tobacco smoke. Crit Rev Toxicol. 1991;21(4):235-240.

140. Aycicek A, Varma M, Ahmet K, Abdurrahim K, Erel O. Maternal active or passive smoking causes oxidative stress in placental tissue. Eur J Pediatr. 2011;170(5):645-651.

141. Aliyu MH, Lynch O, Wilson RE, et al. Association between tobacco use in pregnancy and placenta-associated syndromes: a populationbased study. Arch Gynecol Obstet. 2011;283(4):729-734.

142. Majmundar AJ, Wong WJ, Simon MC. Hypoxia-inducible factors and the response to hypoxic stress. Mol Cell. 2010;40(2):294-309.

143. Miller LL, Henderson J, Northstone K, Pembrey M, Golding J. Do grandmaternal smoking patterns influence the etiology of childhood asthma? Chest. 2014;145(6):1213-1218.

144. Leslie FM. Multigenerational epigenetic effects of nicotine on lung function. BMC Med. 2013;11:27 
145. Kable JA, Coles CD, Lynch ME, Carroll J. The impact of maternal smoking on fast auditory brainstem responses. Neurotoxicol Teratol. 2009;31(4):216-224.

146. Maccani MA, Padbury JF, Marsit CJ. miR-16 and miR-21 expression in the placenta is associated with fetal growth. PLoS One. 2011;6(6):e21210.

147. Paquette AG, Lester BM, Koestler DC, Lesseur C, Armstrong DA, Marsit CJ. Placental FKBP5 genetic and epigenetic variation is associated with infant neurobehavioral outcomes in the RICHS cohort. PLoS One. 2014;9(8):e104913.

148. Lesseur C, Armstrong DA, Paquette AG, Li Z, Padbury JF, Marsit CJ. Maternal obesity and gestational diabetes are associated with placental leptin DNA methylation. Am J Obstet Gynecol. 2014;211(6):654. e1-e9.

149. Lambertini L, Marsit CJ, Sharma P, et al. Imprinted gene expression in fetal growth and development. Placenta. 2012;33(6):480-486.

150. Davis MA, Li Z, Gilbert-Diamond D, et al. Infant toenails as a biomarker of in utero arsenic exposure. J Expo Sci Environ Epidemiol. 2014;24(5):467-473.

151. Joubert BR, Haberg SE, Bell DA, et al. Maternal smoking and DNA methylation in newborns: in utero effect or epigenetic inheritance? Cancer Epidemiol Biomarkers Prev. 2014;23(6):1007-1017.

152. Joubert BR, Haberg SE, Nilsen RM, et al. 450K epigenome-wide scan identifies differential DNA methylation in newborns related to maternal smoking during pregnancy. Environ Health Perspect. 2012;120(10):1425-1431.

153. Cupul-Uicab LA, Baird DD, Skjaerven R, Saha-Chaudhuri P, Haug K, Longnecker MP. In utero exposure to maternal smoking and women's risk of fetal loss in the Norwegian Mother and Child Cohort (MoBa). Hum Reprod. 2011;26(2):458-465.

154. Cupul-Uicab LA, Skjaerven R, Haug K, et al. Exposure to tobacco smoke in utero and subsequent plasma lipids, ApoB, and CRP among adult women in the MoBa cohort. Environ Health Perspect. 2012;120(11):1532-1537.

155. Stene-Larsen K, Borge AI, Vollrath ME. Maternal smoking in pregnancy and externalizing behavior in 18-month-old children: results from a population-based prospective study. J Am Acad Child Adolesc Psychiatry. 2009;48(3):283-289.
156. Novakovic B, Ryan J, Pereira N, Boughton B, Craig JM, Saffery R. Postnatal stability, tissue, and time specific effects of AHRR methylation change in response to maternal smoking in pregnancy. Epigenetics. 2014;9(3):377-386.

157. Breton CV, Siegmund KD, Joubert BR, et al. Prenatal tobacco smoke exposure is associated with childhood DNA CpG methylation. PLoS One. 2014;9(6):e99716.

158. Markunas CA, Xu Z, Harlid S, et al. Identification of DNA methylation changes in newborns related to maternal smoking during pregnancy. Environ Health Perspect. 2014;122(10):1147-1153.

159. Tsaprouni LG, Yang TP, Bell J, et al. Cigarette smoking reduces DNA methylation levels at multiple genomic loci but the effect is partially reversible upon cessation. Epigenetics. 2014;9(10):1382-1396.

160. Zeilinger S, Kuhnel B, Klopp N, et al. Tobacco smoking leads to extensive genome-wide changes in DNA methylation. PLoS One. 2013;8(5):e63812.

161. US Food and Drug Administration. Proposed rule 79 FR 23141. Deeming tobacco products to be subject to the Federal Food, Drug, and Cosmetic Act, as amended by the Family Smoking Prevention and Tobacco Control Act; regulations on the sale and distribution of tobacco products and required warning statements for tobacco products. Fed Regist; 2014:23141-23207.

162. Talih S, Balhas Z, Eissenberg T, et al. Effects of user puff topography, device voltage, and liquid nicotine concentration on electronic cigarette nicotine yield: measurements and model predictions. Nicotine Tob Res. 2015;17(2):150-157.

163. Goniewicz ML, Zielinska-Danch W. Electronic cigarette use among teenagers and young adults in Poland. Pediatrics. 2012;130(4): e879-e885.

164. Carroll Chapman SL, Wu LT. E-cigarette prevalence and correlates of use among adolescents versus adults: a review and comparison. J Psychiatr Res. 2014;54:43-54.

165. Brown J, West R, Beard E, Michie S, Shahab L, McNeill A. Prevalence and characteristics of e-cigarette users in Great Britain: Findings from a general population survey of smokers. Addict Behav. 2014;39(6):1120-1125.
Advances in Genomics and Genetics

\section{Publish your work in this journal}

Advances in Genomics and Genetics is an international, peer reviewed, open access journal that focuses on new developments in characterizing the human and animal genome and specific gene expressions in health and disease. Particular emphasis will be given to those studies that elucidate genes, biomarkers and targets in the development of new or improved therapeutic

\section{Dovepress}

interventions. The journal is characterized by the rapid reporting of reviews, original research, methodologies, technologies and analytics in this subject area. The manuscript management system is completely online and includes a very quick and fair peer-review system. Visit http://www.dovepress.com/ testimonials.php to read real quotes from published authors. 